DOI 10.18551/rjoas.2019-01.58

\title{
THE EFFECTS OF JOB CHARACTERISTICS ON WORK ENGAGEMENT
}

\author{
Prameswari Graceshia Adiarani \\ Department of Industrial and Organizational Psychology, Faculty of Psychology, \\ University of Airlangga, Surabaya, Indonesia \\ E-mail: graceshiaaaa@hotmail.com
}

\begin{abstract}
Work engagement is one of the most important things in achieving company goals because the company's main driving factor is employees. Work engagement refers to the energy that employees have to be directed to organizational goals (Macey, et al., 2009, in Bakker, 2011). Employees who have a high level of engagement will exert more effort in achieving company goals (Sidharta \& Meily, 2012). One of the factors in achieving employee work engagement is job characteristics (Saks, 2006). Job characteristics in this study use Hackman \& Oldham (1974) theory. There are five dimensions in job characteristics (autonomy, feedback, skill variety, task identity and task significance) (Hackman \& Oldham, 1974). This research was conducted to find out whether there is an influence of job characteristics on work engagement. This research was conducted at a port service company located in Surabaya. The samples in this study were 119 employees. The sampling technique used is simple random sampling. The data collection tool in this study is a questionnaire, the Utrecht Work Engagement Scale (UWES) (Schaufeli \& Bakker, 2004) and the scale of the Job Diagnostic Survey (Hackman \& Oldham, 1974). Analysis of the data used is partial least square using the SmartPLS 3.0 program. Based on the results of the study it was found that the five dimensions of job characteristics (autonomy, feedback, skill variety, task identity, and task significance) had a positive and significant relationship to work engagement.
\end{abstract}

\section{KEY WORDS}

Job characteristics, work, engagement, employee engagement.

Work engagement is one construct in positive behaviors of psychology (Bakker \& Demerouti, 2008). Kahn (1990) defines engagement as a situation where employees identify themselves with their jobs. Schaufeli et al (2002) define work engagement as a person's mental condition related to his job, which is characterized by the existence of vigor, dedication and absorption.

Work engagement has certain characteristics that will be useful in achieving organizational goals (Bakker, 2009). Employees who have engagement will express themselves physically, cognitively, and emotionally while carrying out their roles while working (Kahn, 1990). Employees who have engagement will have strong dedication to the organization which is characterized by high involvement in advancing the organization (Schaufeli, et al., 2002). Compared to employees who do not have engagement, employees who have a sense of being bound by their work will work harder, be more resilient in carrying out their work and will exert more effort in achieving company goals (Bakker, 2011; Schaufeli, et al, 2002). Other positive impacts arising from work engagement are increasing employee work performance, organizational commitment, organizational productivity and reduced turnover (Saks, 2006; Bakker \& Demerouti, 2008; Luthans et al., 2010).

One of the factors in achieving employee work engagaement is job characteristics (Saks, 2006). Job characteristics are inherent in a job, where the characteristics of this work have aspects or components that can lead to a full understanding of a job, a sense of responsibility for work results, a sense of concern for the impact of work, and also produce courtesy norms positive for employees, to further influence the engagement of employee (Hackman \& Oldham, 1974). In addition, work that has a core characteristic of work with special characteristics will provide space for employees to be more engaged to their work (Kahn, 1992). 
Thus, the characteristics of work that have special characteristics will have an impact on increasing employee intrinsic motivation, increasing job satisfaction and reducing the pressure on job demands. In addition, employees with job characteristics with special characteristics will feel challenged by the demands given, so that they can complete their work effectively.

\section{LITERATURE REVIEW}

The concept of engagement was first introduced by Kahn in 1990. Kahn (1990) said that engagement is a situation where employees identify themselves with their work. Employees who have engagement will express themselves physically, cognitively and emotionally at work. Kahn (1990) added that engagement is a condition of optimal use of self that is present both physically and psychologically in carrying out its role as an employee in the organization.

Rothbard (2001) perceives engagement as a psychological presence that involves two components, namely attention and absorption. Attention is defined as the involvement of cognitive aspects and the amount of time a person spends thinking about their work, while absorption is defined as the feeling of being lured (feeling engrossed) towards work which is characterized by intensity in focusing on work. Schaufeli, et al. (2002) define work attachment as a person's mental condition related to his work, which is characterized by the presence of vigor, dedication and absorption.

A job cannot be designed only by using elements that encourage effectiveness (Werther \& Davis, 1993). Therefore an organization should be able to provide a work environment that helps meet individual needs through job design. Job design is the process of defining work procedures and tasks that are needed for each job (Noe et al, 2015). Organizations need jobs that are in demand and provide satisfaction for their employees, so that it can motivate employees to work. One approach taken in designing work is to perform job characteristics (Noe, et al, 2015).

Hackman \& Oldham (1974) explains that job characteristics are a set of variables that relate the nature of the work core to situations that are generally considered to be the main causes of employee behavior. There are five dimensions in job characteristics, namely autonomy, feedback, skill variety, task identity, and task significance (Hackman \& Oldham, 1974).

$\mathrm{H} 1$ : Job characteristic will be positively related to work engagement.

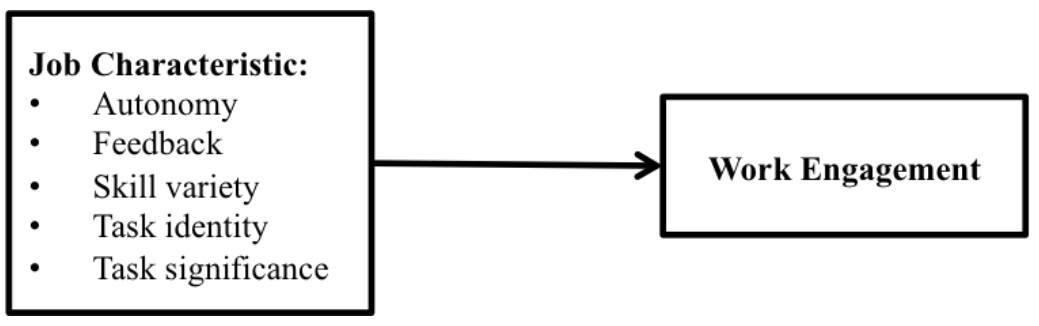

Figure 1 - Conceptual Model

\section{METHODS OF RESEARCH}

The population in this study is permanent employees at a port service company in Surabaya. The samples in this study were 119 employees.

The scale used to measure work engagement is the Utrecht Work Engagement Scale (UWES) scale belonging to Schaufeli \& Bakker (2004). This scale consists of 17 item statements and uses a choice of answers with a seven-point Likert scale of 1 (never at all) to 7 (always). The scale used to measure job characteristics is the scale of Hackman \& Oldham's (1974) Job Diagnostic Survey. This scale consists of 18 item statements and uses a choice of answers with a seven-point Likert scale from 1 (very inappropriate) to 7 (very appropriate). The scale in this study shows adequate internal consistency. 
Table 1 - Profile of Respondents

\begin{tabular}{|c|c|c|c|}
\hline Variable & Description & $\mathrm{N}$ & $\%$ \\
\hline \multirow{2}{*}{ Gender } & Male & 81 & 68 \\
\hline & Female & 38 & 32 \\
\hline \multirow{3}{*}{ Age } & 23 to 27 & 23 & 18 \\
\hline & 28 to 32 & 59 & 50 \\
\hline & 33 to 37 & 37 & 32 \\
\hline \multirow{4}{*}{ Years working at current organization } & $1-2$ years & 37 & 31 \\
\hline & $2-3$ years & 12 & 10 \\
\hline & 3-4 years & 34 & 29 \\
\hline & $>4$ years & 36 & 30 \\
\hline \multirow{2}{*}{ Field of work } & Operational & 65 & 55 \\
\hline & Non operational & 54 & 45 \\
\hline
\end{tabular}

Table 2 - Results of Reliability Analysis

\begin{tabular}{lcccc}
\hline & Variable & & Number of Item & $\alpha$ \\
\hline \multirow{3}{*}{ Job Characteristic } & Autonomy & 3 & 0,620 \\
\cline { 2 - 4 } & & Feedback & 6 & 0,718 \\
\cline { 2 - 4 } & Skill Variety & 3 & 0,699 \\
\cline { 2 - 4 } & \multicolumn{2}{c}{ Task Identity } & 3 & 0,810 \\
\cline { 2 - 4 } & \multicolumn{2}{c}{ Task Significance } & 3 & 0,659 \\
\cline { 3 - 5 } & \multicolumn{2}{c}{ Work Engagement } & 17 & 0,944 \\
\hline
\end{tabular}

\section{RESULTS AND DISCUSSION}

The data analysis used in this study is Partial Least Square (PLS). This analysis is used to predict the relationship between constructs and develop theories. The purpose of this study is to find out whether there are influences of job characteristics on work engagement.

Table 1 - Means, Standard Deviation, and Correlation among Variables

\begin{tabular}{|c|c|c|c|c|c|c|}
\hline \multicolumn{2}{|c|}{ Variable } & Mean & SD & Adj.R2 & CR & AVE \\
\hline \multirow{5}{*}{ Job Characteristic } & Autonomy & 14,65 & 2,76 & & 0,839 & 0,723 \\
\hline & Feedback & 28,74 & 4,63 & & 0,841 & 0,640 \\
\hline & Skill Variety & 14,69 & 3,04 & & 0,799 & 0,666 \\
\hline & Task Identity & 15,82 & 3,17 & & 0,913 & 0,841 \\
\hline & Task Significance & 16,23 & 2,92 & & 0,853 & 0,744 \\
\hline \multicolumn{2}{|c|}{ Work Engagement } & 87,63 & 15,15 & 0,476 & 0,953 & 0,695 \\
\hline
\end{tabular}

$S D=$ standard deviation; Adj. $R 2$ = adjusted $R$-squared; $C R=$ composite reliability; $A V E$ = average variance extracted.

Table 2 - Model Results

\begin{tabular}{ccc}
\hline Path & T-values & P-values \\
\hline Autonomy $\rightarrow$ Work Engagement & 6,602 & 0,000 \\
\hline Feedback $\rightarrow$ Work Engagement & 5,214 & 0,000 \\
\hline Skill Variety $\rightarrow$ Work Engagement & 5,506 & 0,000 \\
\hline Task Identity $\rightarrow$ Work Engagement & 6,554 & 0,000 \\
\hline Task Significance $\rightarrow$ Work Engagement & 5,619 & 0,000 \\
\hline
\end{tabular}

Based on the above findings, autonomy $(t=6.60, p=.000)$, feedback $(t=5.21, p=$ $.000)$, skill variety $(t=5.50, p=.000)$, task identity $(t=6.55, p=.000)$ and task significance $(t$ $=5.61, p=.000$ ) were positive and significant on work engagement. Job characteristic showed positive relation with work engagement. The findings of the above study were consistent with previous studies, Sejati (2012), Meinarty (2015) and Nadhir \& Puteh (2017), which proves that there is a positive and significant influence of job characteristics on work engagement.

In the autonomy dimension, the autonomy that is given will make employees feel given more trust and respect by the organization in doing its work, so that in the employee will grow feelings of bound employees towards work and organization (Hackman \& Oldham, 1974). In 
the feedback dimension, when employees get feedback on how successful they are at their jobs, employees will feel they are getting guidance and will motivate them to perform better (Werther \& Davis, 1993). In the skill variety dimension, the diversity of skills on the job can lead to a feeling of great competency for employees, so it can make employees stay in the organization and eliminate the boredom that arises from repetitive work activities. On the dimensions of task identity, tasks or jobs that are identified will increase productivity and job satisfaction of employees, so that they will be responsible for completing all their work because they already have a clear workflow (Werther \& Davis, 1993). On the dimension of task significance, when employees consider the work they do gives meaning that is meaningful especially for the organization, then there will be a great sense of responsibility in completing work. This sense of responsibility will lead to encouragement for employees to try harder in completing their work (Hackman \& Oldham, 1974).

Thus, it can be concluded about the characteristics of work inherent in a job, where the characteristics of this job have aspects that can affect the understanding of work, a sense of responsibility for work results, a sense of concern for changes that occur from work, and also produce positive politeness norms to employees, to further increase work engagement (Hackman \& Oldham, 1974).

\section{CONCLUSION AND SUGGESTIONS}

Based on the results of the research that has been done, it can be concluded that job characteristics have a positive and significant influence on work engagement. Individuals with high job characteristics will lead to increased levels of work engagement. Likewise, vice versa, individuals with low job characteristics will cause a decrease in the level of work engagement.

In further research, it is expected to be able to measure work engagement in different organizations of this study, or can be specifically researched at certain positions or levels in an organization, in order to be able to provide comprehensive information about work attachments measured from a position or level perspective or certain organization.

\section{REFERENCES}

1. Bakker, A.B. (2009). Building engagement in the workplace. In R. J. Burke \& C.L. Cooper (Eds.): The peak performing organization, 50-72.

2. Bakker, A.B. (2011). An evidence-based model of work engagement. Current Directions in Psychological Science, 20(4), 265-269.

3. Bakker, A.B., \& Demerouti, E. (2008). Towards a model of work engagement. Career Development International, 13(3), 209-223.

4. Hackman, J.R. \& Oldham, G.R. (1974). The Job Diagnostic Survey: An Instrument for The Diagnosis of Jobs and The Evaluation of Job Redesign Projects. Department of Administrative Sciences: Yale University.

5. Kahn, W.A. (1990). Psychological Conditions of Personal Engagement \& Disengagement at Work. Academy of Management Journal, 33(4),692- 724.

6. Luthans, F., Avey, J.B., Avolio, B.J., \& Peterson, S. J. (2010). The development and resulting performance impact of positive psychological capital. Human Resources Development Quarterly, 21(1), 41-67.

7. Meinarty, M. (2015). Analysis of the Effect of Job Characteristic and Perceived Organizational Support on Employee Engagement (Case Study at the Head Office of Perum Perhutani). Theses. Paper 99.

8. Nadhir, N.H.M. \& Puteh, F. (2017). Impact assessment of job characteristics model on employee engagement. E-Academia Journal, 6(1), 28-37.

9. Noe, R. A., Hollenbeck, J.R., Gerhart, B. \& Wright, P.M. (2015). Fundamentals of Human Resource Management. New York: McGraw-Hills.

10. Rothbard, N.P. (2001). Enriching or depleting? The dynamics of engagement in work and family roles. Administrative Science Quarterly, 46, 84-655. 
11. Saks, A.M. (2006). Antecendents and consequences of work engagement. Journal of Managerial Psychology, 600-619.

12. Schaufeli W.B. \& Bakker, A. (2004). Utrecht work engagement scale. Premilinary Manual Version 1.1. Ocupational Health Psychology. Timisoara: Utrecht University.

13. Schaufeli, W.B., Salanova, M., Gonzales-Roma, V., \& Bakker, A. (2002). The measurement of engagement and burnout: A two sample confirmatory factor analytic approach. Journal of Happiness Studies, 3, 71-92.

14. Sejati, A. (2012). Effect of Job Characteristic on Employee Engagement at PT. Wijaya Karya Beton Head Office. Theses. Paper 95.

15. Sidharta, N. \& Meily, M. (2012). Impact of organizational commitment and job satisfaction on turnover intentions (empirical studies on employees of operator parts in one of the garment companies in Cimahi). Management Journal, Maranatha Christian University, 10(2), 129-142.

16. Werther, W. B., \& Davis, K. (1993). Human Resources and Personel Management. Singapore: McGraw-Hills. 